\title{
Hepatitis B antigen and antibody in the blood of prostitutes visiting an outpatient venereology department in Rotterdam
}

\author{
D DE HOOP,* W J J ANKER, † R VAN STRIK, $\neq N$ MASUREL,† AND E STOLZ* \\ From the *Department of Dermatovenereology, University Hospital, Rotterdam-Dijkzigt, and the \\ Departments of $\uparrow$ Virology and $¥$ Biostatistics, Erasmus University, Rotterdam, The Netherlands
}

SUMMARY We took blood samples from 128 prostitutes visiting the outpatient venereology department of the University Hospital, Rotterdam-Dijkzigt to test for the presence of hepatitis B surface antigen (HBsAg) and antibody to hepatitis B surface antigen (anti-HBs). The prevalence of anti-HBs was found to be significantly higher in the group of prostitutes than in "normal populations", and we concluded that more of the former had been in contact with the hepatitis B virus (HBV). We recommend that the advice on vaccination of the hepatitis B committee of the Health Council of The Netherlands should be followed by screening prostitutes for the presence of HBsAg and anti-HBs in the blood, and vaccinating those who have no anti-HBs.

\section{Introduction}

Various authors have pointed to the link between promiscuity, homosexuality, drug use, and the carrier state for hepatitis B surface antigen (HBsAg) or antibody (anti-HBs). ${ }^{1-7}$ As HBsAg is found in the body fluids and in secretions, its sexual transmission seems possible and even probable. Saliva is the secretion most often named as a transmitter of $\mathbf{H B s A g}{ }^{8-10}$ Although transmission of hepatitis B virus (HBV) by the oral route has been shown by Krugman et al, ${ }^{11}$ the results of the study by Bodansky appear to contradict this. ${ }^{12}$ Research into the occurrence of $\mathrm{HBsAg}$ and anti-HBs has been carried out on, among others, male homosexuals and promiscuous women, particularly prostitutes. ${ }^{13-16}$ As a result we undertook a study on the occurrence of $\mathrm{HBsAg}$ and anti-HBs in the blood of prostitutes who visited the outpatient venereology department of the University Hospital, Rotterdam-Dijkzigt, and compared the results with data from previously published studies.

\section{Patients and methods}

PATIENTS

In the period from 1 January to 1 July 1982 we took blood samples to test for the presence of HBsAg and

Address for reprints: Professor E Stolz, Academisch Ziekenhuis Dijkzigt, dr molewaterplein 40, 3015 GD Rotterdam, Holland

Accepted for publication 27 October 1983
anti-HBs from 128 prostitutes who visited this hospital's outpatient venereology department. Blood samples that gave positive results for $\mathrm{HBsAg}$ were also screened for the presence of hepatitis Be antigen $(\mathrm{HBeAg})$ and antibody to hepatitis Be antigen (anti$\mathrm{HBe})$.

\section{LABORATORY STUDIES}

We used a radioimmunoassay to show HBsAg and $\mathrm{HBeAg}$, and the Australia antigen Surface antibody (Au Sab) test (Abbott Laboratories, North Chicago, Illinois, United States of America) to show anti-HBs and anti-HBe. We recorded the age and nationality of each woman. Where the results were positive for HBsAg, anti-HBs, or both we asked the patient about previous liver disease, and whether she had been jaundiced at any time.

The results obtained were compared with data on the prevalence of HBsAg in female Dutch blood donors of comparable ages in Rotterdam, which were supplied by the head of the Rotterdam Blood Transfusion Service, Dr F C Kothe. We also compared our results with the prevalence of $\mathrm{HBsAg}$ and anti-HBs in some "normal populations" in Europe and Canada as reported by Sobeslavsky. ${ }^{17}$

STATISTICAL ANALYSIS

In the statistical evaluation of our results the age dependence of prevalences was determined using the trend test for percentage frequencies. ${ }^{21}$ To judge the reliability of observed prevalences in the different categories we calculated the corresponding $95 \%$ con- 
fidence intervals. ${ }^{21}$ Differences in prevalences were evaluated with the Fisher test, or the $\chi^{2}$ approach for this test. ${ }^{21}$

\section{Results}

Table I gives the age distribution of the 128 prostitutes divided into Dutch and foreign nationality.

Three $(2 \cdot 3 \%)$ of the 128 samples gave positive results for $\mathrm{HBsAg}$ and negative results for $\mathrm{HBeAg}$; two of them had HBs. Two of the patients from whom these samples had been taken were aged 23, and the third was aged 29, and they were all Dutch. None of them had clinical evidence of hepatitis. Of the 128 samples, 42 contained anti-HBs; 31 of these samples were from Dutch and 11 from foreign prostitutes. None of these women remembered having had clinical evidence of hepatitis.

TABLE I Age distribution of 128 Dutch and foreign prostitutes in five year groups

\begin{tabular}{lccc}
\hline Age group & Dutch & Foreign & Total \\
\hline $50-54$ & 1 & & 1 \\
$45-49$ & 3 & & 3 \\
$40-44$ & 7 & 1 & 8 \\
$35-39$ & 10 & 2 & 12 \\
$30-34$ & 21 & 7 & 28 \\
$25-29$ & 25 & 12 & 37 \\
$20-24$ & 28 & 7 & 35 \\
$15-19$ & 3 & 1 & 4 \\
Total & 98 & 30 & 128 \\
\hline
\end{tabular}

Table II shows the nationalities of the $\mathbf{3 0}$ foreign prostitutes, and the occurrence of anti-HBs among them.

Table III shows the prevalence of $\mathrm{HBsAg}$, antiHBs, or both in Dutch and foreign prostitutes related to age. In the group of all 45 prostitutes who gave positive results for $\mathrm{HBsAg}$, anti-HBs, or both no significant trend of prevalence with age was found (trend tests, $p>0.05$ ). The same applies to the groups of Dutch and foreign prostitutes considered separately. There was no significant difference $\left(\chi^{2}\right.$ test, $\mathrm{p}>0.05$ ) between Dutch and foreign prostitutes with HBsAg, anti-HBs, or both. In the total of 128 it can
TABLE II Nationalities of 30 foreign prostitutes and prevalence of anti-HBs

\begin{tabular}{lcc}
\hline Country of origin & $\begin{array}{l}\text { Occurrence of } \\
\text { anti-HBs }\end{array}$ & Total \\
\hline Surinam & 4 & 6 \\
Morocco & 2 & 2 \\
Tunisia & 1 & 1 \\
Germany & 1 & 3 \\
England & 1 & 3 \\
Spain & 1 & 2 \\
Philippines & 1 & 1 \\
Portugal & & 2 \\
Brazil & & 1 \\
Indonesia & & 1 \\
France & & 3 \\
Sweden & 2 \\
Cabo Verde & & 2 \\
Belgium & & 1 \\
Total & 11 & 30 \\
\hline
\end{tabular}

be concluded that, with a confidence coefficient of 0.95 , between $0.5 \%$ and $6.7 \%$ serum samples should be positive for HBsAg and between $25 \%$ and $42 \%$ should be positive for anti-HBs.

Table IV shows the prevalence of HBsAg and that of anti-HBs in Dutch and foreign prostitutes. In view of the overlapping of the corresponding confidence intervals, there was no significant difference $(p>0.05)$ between Dutch and foreign prostitutes with $\mathrm{HBsAg}$ or anti-HBs.

In a total of 936 new female blood donors who registered at the Red Cross Laboratory in Rotterdam in the first half of 1982 , serum from two $(0 \cdot 2 \%)$ contained HBsAg. In these 936 women it can be con-

TABLE III Prevalence of $\mathrm{HBs} A \mathrm{~g}$, anti-HBs, or both among Dutch and foreign prostitutes related to age

\begin{tabular}{lccr}
\hline & \multicolumn{3}{l}{ No positive/No tested } \\
\cline { 2 - 4 } Age group $^{*}$ & Dutch & Foreign & Total (\%) \\
\hline $50-54$ & $4 / 11$ & $0 / 1$ & $4 / 12(33)$ \\
$35-39$ & $1 / 10$ & $1 / 2$ & $2 / 12(17)$ \\
$30-34$ & $8 / 21$ & $2 / 7$ & $10 / 28(36)$ \\
$25-29$ & $10 / 25$ & $4 / 12$ & $14 / 37(37)$ \\
$15-24$ & $11 / 31$ & $4 / 8$ & $15 / 39(38)$ \\
Total & $34 / 98$ & $11 / 30$ & $45 / 128(35)$ \\
\hline
\end{tabular}

*Arranged so that there were at least 12 in each group.

TABLE IV Prevalence of HBsAg and anti-HBs in Dutch and foreign prostitutes

\begin{tabular}{|c|c|c|c|c|}
\hline \multirow[b]{2}{*}{ Nationality } & \multicolumn{2}{|l|}{$H B s A g$} & \multicolumn{2}{|l|}{$A n t i-H B s$} \\
\hline & $\begin{array}{l}\text { No positivel } \\
\text { No tested }(\%)\end{array}$ & $\begin{array}{l}95 \% \\
\text { confidence } \\
\text { interval }\end{array}$ & $\begin{array}{l}\text { No positivel } \\
\text { No tested }(\%)\end{array}$ & $\begin{array}{l}95 \% \\
\text { confidence } \\
\text { interval }\end{array}$ \\
\hline $\begin{array}{l}\text { Dutch } \\
\text { Foreign }\end{array}$ & $\begin{array}{ll}3 / 98 & (3 \cdot 1) \\
0 / 30 & (0)\end{array}$ & $\begin{array}{l}0 \cdot 16-8 \cdot 7 \% \\
0-11 \cdot 6 \%\end{array}$ & $\begin{array}{ll}31 / 98 & (32) \\
11 / 30 & (37)\end{array}$ & $\begin{array}{l}23-42 \% \\
20-56 \%\end{array}$ \\
\hline Total & $3 / 128(2 \cdot 3)$ & $0 \cdot 5-6 \cdot 7 \%$ & $42 / 128(33)$ & $25-42 \%$ \\
\hline
\end{tabular}


cluded that, with a confidence coefficient of 0.95 , between $0.02 \%$ and $0.7 \%$ women should be HBsAg positive. The prevalence $(3 \cdot 1 \%)$ of $\mathrm{HBsAg}$ in the group of Dutch prostitutes studied did not differ significantly $\left(\chi^{2}\right.$ test, $\left.\mathrm{p}>0.05\right)$ from the above prevalence $(0 \cdot 2 \%)$ in blood donors.

Table $\mathrm{V}$ shows the prevalence of $\mathrm{HBsAg}$ and antiHBs found by Sobeslavsky" in "normal populations" of men and women in Ottawa (Canada), Berlin (East Germany), Göttingen (West Germany), and Munich (West Germany). From this table it can be seen that, in view of the overlapping of the $95 \%$ confidence intervals, the differences between the prevalences of HBsAg in the four cities were not significant. The prevalence of anti-HBs in Berlin was considerably greater than in the other cities, in each of which it was about $4 \%$. The prevalence of $\mathrm{HBsAg}$ in our patients (table IV) did not differ appreciably from that given in table $V$, whereas the prevalence of anti-HBs in our study (table IV) was considerably greater than that given in table $\mathrm{V}$.

\section{Discussion}

None of our patients with HBsAg had clinical symptoms of hepatitis. The patients most likely to transmit $\mathrm{HBV}$ are those with $\mathrm{HBeAg}$, whereas those with $\mathrm{HBsAg}$ and anti-HBe are unlikely to transmit the infection by sexual contact. ${ }^{22}$ As the blood of two of our patients with $\mathrm{HBsAg}$ was positive for anti$\mathrm{HBe}$, they were unlikely to transmit the infection by sexual contact. Moreover, none of the 42 patients with anti-HBs was aware of ever having suffered from hepatitis B. Especially in the case of the foreign prostitutes, however, one possibility is that an HBV infection was acquired in childhood, as occurs in a number of subtropical and tropical countries. It is notable that all three patients with $\mathrm{HBsAg}$ were Dutch. A striking feature among the foreign prostitutes was the relatively large number of Surinamese women who had anti-HBs (four of the total of 11 women with anti-HBs, and four of the six
Surinamese women) (table II). In contrast to the results of Frösner et al, ${ }^{16}$ we were unable to show a noticeable correlation of prevalence with age (table III).

We have no satisfactory explanation for the fact that there was no appreciable difference in the prevalence of HBsAg, anti-HBs, or both between Dutch and foreign prostitutes (table III). It is not impossible that foreign, in particular Surinamese, prostitutes had already come into contact with HBV in childhood, while Dutch prostitutes come into contact with hepatitis B virus only later, during sexual activity. The number of years of prostitution and the type of prostitution (for example, heroin prostitution) are probably important factors regarding contact with HBV.

There are widely differing reports of the prevalence of HBsAg and anti-HBs. Adam et al found no appreciable differences between prostitutes, nuns, female residents in certain homes, and a control group in prevalence of $\mathrm{HBsAg}$ and anti-HBs. ${ }^{13}$ Similarly, Papaevangelou et al found no appreciable differences in prevalence of $\mathrm{HBsAg}$ between 293 prostitutes and 379 pregnant women of the same age and social class; the prevalence was $4 \cdot 4 \%$ and $3 \cdot 4 \%$ respectively. The prevalence of anti-HBs in the first group $(56 \cdot 7 \%)$, however, was significantly higher than that in the second group (24.5\%). ${ }^{14}{ }^{15}$ Frösner et al studied the prevalence of anti-HBs in populations with different levels of promiscuity. ${ }^{16}$ They found $31 \%$ in 258 prostitutes, $10 \%$ in 258 female blood donors, $10 \%$ in 48 nuns in a convent, and $15 \%$ in 94 nuns working in education. In each group the prevalence of anti-HBs increased with age. In the age group 40-49 years, for example, $72 \%$ of the prostitutes and $23 \%$ of the blood donors had anti-HBs.

The prevalence of HBsAg found in our study in Dutch prostitutes (table IV) was not appreciably higher than in the female Dutch blood donors of comparable ages in Rotterdam. The prevalence of anti-HBs in the group of prostitutes studied by us

TABLE v Prevalence of $\mathrm{HBs} \mathrm{Ag}$ and anti-HBs in some "normal populations" of men and women in Ottawa, Berlin, Göttingen, and Munich ${ }^{17}$

\begin{tabular}{|c|c|c|c|c|}
\hline \multirow[b]{2}{*}{ City } & \multicolumn{2}{|l|}{$H B s A g$} & \multicolumn{2}{|l|}{$A n t i-H B s$} \\
\hline & $\begin{array}{l}\text { No positivel } \\
\text { No tested }(\%)\end{array}$ & $\begin{array}{l}95 \% \\
\text { confidence } \\
\text { interval }\end{array}$ & $\begin{array}{l}\text { No positivel } \\
\text { No tested }(\%)\end{array}$ & $\begin{array}{l}95 \% \\
\text { confidence } \\
\text { interval }\end{array}$ \\
\hline $\begin{array}{l}\text { Ottawa } \\
\text { Berlin } \\
\text { Göttingen } \\
\text { Munich }\end{array}$ & $\begin{array}{cl}7 / 1177(0 \cdot 6) \\
7 / 438(1 \cdot 6) \\
0 / 159(0) \\
22 / 1799(1 \cdot 2)\end{array}$ & $\begin{array}{l}0 \cdot 3-1 \cdot 3 \% \\
0 \cdot 6-3 \cdot 3 \% \\
0-2 \cdot 3 \% \\
0 \cdot 8-1 \cdot 9 \%\end{array}$ & $\begin{array}{c}52 / 1217(4 \cdot 3) \\
43 / 311(13 \cdot 8) \\
7 / 159(4 \cdot 4) \\
67 / 1799(3 \cdot 7)\end{array}$ & $\begin{array}{c}3 \cdot 2-5 \cdot 6 \% \\
10 \cdot 2-18 \cdot 2 \% \\
1 \cdot 8-8 \cdot 9 \% \\
2 \cdot 9-4 \cdot 7 \%\end{array}$ \\
\hline Total* & $29 / 3135(0.9)$ & $0 \cdot 6-1 \cdot 3 \%$ & $126 / 3175(4 \cdot \theta)$ & $3 \cdot 3-4 \cdot 7 \%$ \\
\hline
\end{tabular}

*Excluding Berlin. 
was significantly higher than that found in "normal populations" in Ottawa, Berlin, Göttingen, and Munich (see tables IV and V). From these results we conclude that prostitutes have a greater chance of coming into contact with HBV than people in control groups. In view of their sexual behaviour, they also have more opportunity to spread HBsAg. Although we do not know the date of acquisition of HBV by prostitutes, we subscribe to the view of the hepatitis B committee of the Health Council that prostitutes belong to groups of healthy people who, because of exceptional circumstances, are continuously or incidentally exposed to HBV infection. ${ }^{18}$ It seems desirable that the regular sexual partners of prostitutes should also be classed in these groups, partly on the basis of the findings of Grady ${ }^{19}$ and Inaba et al. ${ }^{20}$

We advocate following the interim vaccination advice of the hepatitis $B$ committee that, partly to prevent the transmission of HBV to clients, prostitutes who have not yet been infected with HBV should be given the opportunity to have themselves vaccinated against this viral infection. This requires regular screening of prostitutes for anti-HBs and HBsAg.

\section{References}

1. Bleeker A, Coutinho RA, Bakker-Kok J, Tio D, de Koning GAJ. Prevalence of syphilis and hepatitis B among homosexual men in two saunas in Amsterdam. Br J Vener Dis 1981; 57: 196-9.

2. Lim KS, Taam Wong V, Fulford KWM, et al. Role of sexual and non-sexual practices in the transmission of hepatitis B. BrJ Vener Dis 1977;53:190-2.

3. Coleman JC, Waugh M, Dayton R. Hepatitis B antigen and artibody in a male homosexual population. Br J Vener Dis 1977; 53:132-4.
4. Coutinho RA, Schut BJT, Albrecht-van Lent N, ReeringBrongers EE. Hepatitis B among homosexual men in the Netherlands. Sex Transm Dis 1981;8:333-5.

5. William DC. Hepatitis and other sexually transmitted diseases in gay men and in lesbians. Sex Transm Dis 1981;8:330-2.

6. Szmuness W, Much MI, Prince AM, et al. On the role of sexual behaviour in the spread of hepatitis B infections. Ann Int Med 1975;83:489-95.

7. van Beek-Verbeek G. Het vóórkomen van hepatitis B-antigeen en -antistoffen in het bloed van verslaafden aan drugs. Ned Tijdschr Geneeskd 1979; 23:1144-7.

8. Heathcote J, Cameron CH, Dane DS. Hepatitis B antigen in saliva and semen. Lancet 1974; i: 71-3.

9. Villarejos VM, Visona PHKA, Alvaro Gutierrez D, Antonio Rodriguez A. Role of saliva, urine and feces in the transmission of type B hepatitits. N Engl J Med 1974;292:1375-8.

10. Ward R, Borchert P, Wright A, Kline E. Hepatitis B antigen in saliva and mouth washings. Lancet 1972; ii: 726-9.

11. Krugman S, Giles JP, Hammond J. Infectious hepatitis. JAMA 1967; 200:365-73.

12. Bodansky HJ. Lack of transmission of viral hepatitis type B after oral exposure to $\mathrm{HBsAg}$ positive saliva. $\mathrm{Br}$ Med $J$ 1979; ii: $1263-4$.

13. Adam E, Blaine Hollinger F, Melnick JL, Dueñas A, Rawls WE. Type B hepatitis antigen and antibody among prostitutes and nuns. A study of possible venereal transmission. J Infect Dis 1974; 129:317-21.

14. Papaevangelou $G$, Trichopoulos $D$, Kremastinou $T$, Papoutsahis G. Prevalence of hepatitis B antigen and antibody in prostitutes. $\mathrm{Br}$ Med $J$ 1974; ii:256-8.

15. Papaevangelou G, Trichopoulos D, Papoutsahis G, Kremastinou T, Pavlides E. Hepatitis B antigen in prostitutes. Br J Vener Dis 1974; 50:228-31.

16. Frösner GG, Buchholz HM, Gerth HJ. Prevalence of hepatitis B antibody in prostitutes. Am J Epidemiol 1975; 102:241-50.

17. Sobeslavsky $O$. Prevalence of markers of hepatitis B virus infection in various countries: a WHO collaborative study. Bull WHO 1980;58:621-8.

18. Van der Heide J. Vaccinatie tegen hepatitis B: een interim advies van de Gezondheidsraad. Ned Tijdschr Geneeskd 1982; 126: 1556-7.

19. Grady GF. Strategies for prevention of hepatitis $B$ as a sexually transmitted disease. Sex Transm Dis 1981;8:344-8.

20. Inaba N, Ohkawa R, Matsuura A, Kudoh J, Takamizawa $H$. Sexual transmission of hepatitis $B$ surface antigen. Infection of husbands by HBsAg carrier-state wives. Br J Vener Dis 1979; 55:366-8.

21. Fieiss JL. Statistical methods for rates and proportions. New York: Wiley, 1981.

22. Pastore G, Dentico P, Angarano G, Lapedota E, Schiraldi O. Infectivity markers in $\mathrm{HBsAg}$ carriers and intrafamilial spread of hepatitis B virus infection. Hepato-Gastroenterol 1981; 28:20-2. 